\title{
37. GONDWANALAND DISPERSAL AND THE EARLY FORMATION OF THE INDIAN OCEAN'
}

\author{
Bruce P. Luyendyk, ${ }^{2}$ Department of Geology and Geophysics, Woods Hole Oceanographic Institution, \\ Woods Hole, Massachusetts
}

\begin{abstract}
Deep Sea Drilling results in the Indian Ocean and mapping of Mesozoic magnetic anomalies allow construction of a model for the plate system in the early Indian Ocean.
\end{abstract}

In spite of the fact that the concept of Gondwanaland, the late Paleozoic supercontinent of the Southern Hemisphere, has been extant for over 50 years (Wegener, 1929; DuToit, 1937), the details of the exact configuration of its component continents and the dispersal of these continents via plate motions with time, remain largely speculative. Recent interpretations of marine magnetic anomalies in the Indian Ocean together with Deep Sea Drilling Project (DSDP) results (Figure 1), put sufficient restraints on the dispersal of the Gondwana continents that it is possible to construct a plate model for the early formation of the Indian Ocean. Major insights in this area have been provided by McKenzie and Sclater (1971) and Falvey (1972a, b). McKenzie and Sclater (1971), using Cenozoic marine magnetic anomalies, accurately reconstructed the relative position of the Gondwana continents ${ }^{3}$ in the Late-Cretaceous/early-Tertiary period. Falvey (1972b) presented some novel ideas on the configuration of the Mesozoic plate system in the eastern part of the Indian Ocean. Some particular questions which are left unanswered by these studies are: (1) where was India located in Gondwanaland, against west Australia (Veevers et al., 1971; Crawford, 1969) or against Antarctica (DuToit, 1937; Falvey, 1972B); (2) how did the Gondwana continents disperse in time, to arrive at the relative positions that McKenzie and Sclater (1971) determined? Because the breakup and dispersal of Gondwanaland covered a time span including a mid- to Late-Cretaceous period of nonreversal of the earth's magnetic field (85-111 m.y. as suggested by Larson and Pitman, 1972), sea-floor chronology prior to the earliest McKenzie and Sclater reconstruction (Late Cretaceous or younger) cannot be deduced from marine magnetic anomalies unless sea floor older than about 110 m.y. can be found. Therefore, the early history of the Indian Ocean can only be determined by deep drilling in sea floor thought to be older than Late Cretaceous(i.e. Cloniacian, anomaly 32 of Heirtzler et al., 1968). Using DSDP data and Cretaceous and Tertiary magnetic

\footnotetext{
'Woods Hole Oceanographic Institution, Contribution No. 3249.

${ }^{2}$ Now at Department of Geological Sciences, University of California at Santa Barbara, Santa Barbara, California.

${ }^{3}$ The Gondwana continents include: South America, Africa, India (with Ceylon), Madagascar, Australia, and Antarctica, plus microcontinents such as the Seychelles.
}

anomalies mapped off west Australia, a model is suggested which requires India to fit against Antarctica, for Gondwanaland to disperse first in the eastern Indian Ocean and extreme southern Atlantic, followed by dispersal in the western Indian Ocean and equatorial regions of the South Atlantic. This model should only be considered an outline sketch of early dispersal. Ultimately, a more rigorous story should be constructed with determinations of poles of rotation, finite rotations, and paleomagnetic latitudes.

Deep Sea Drilling Project holes (von der Borch, Sclater, et al., 1972; Luyendyk, Davies, et al., 1973; Heirtzler, Veevers, et al., 1973b) in the eastern Indian Ocean (Wharton Basin) along with magnetic lineations recently charted, can be interpreted to show that the seafloor isochrons here run east-west and that the sea floor is oldest in the south (Sclater and Fisher, in press, and Figure 2). The oldest known sea floor in the Indian Ocean is Late Jurassic (Oxfordian) and is found northwest of Australia in the North Australian Basin (Heirtzler et al., 1973a). The sea floor here is older than that in the southern Wharton Basin, implying that rifting and spreading occurred here first. East-westtrending marine magnetic anomalies have been mapped in the northern Wharton Basin by Sclater and Fisher (in press) and Lowrie et al., (1972), and in the North Australian Basin by Falvey (1972b). These anomalies are early Tertiary in the northern Wharton Basin, and evidently Early Cretaceous in the North Australia Basin. Earlier, Falvey (1972b) apparently misidentified this latter set of anomalies as Cenozoic, but the drilling results imply they are older. Attempts to model this sequence using Larson and Pitman's (1972) Mesozoic time scale and various combinations of spreading rates and skewness, $\theta$ (Schouten and McCamy, 1972) have not yet been successful, and there is some doubt as to whether these anomalies are related to sea-floorspreading processes.

The distribution of isochrons in Figure 2 indicates that eastern India was most likely against Antarctica in Gondwanaland as suggested earlier by DuToit (1937), McElhinney (1970), Falvey (1972b), and Smith and Hallam (1970), and that the dispersal plate system was initiated first off northwest Australia, followed by spreading between India and Antarctica. Figure 3a shows an east-west-trending ridge off northern Australia and India (?) in the Late Jurassic. This ridge may have 


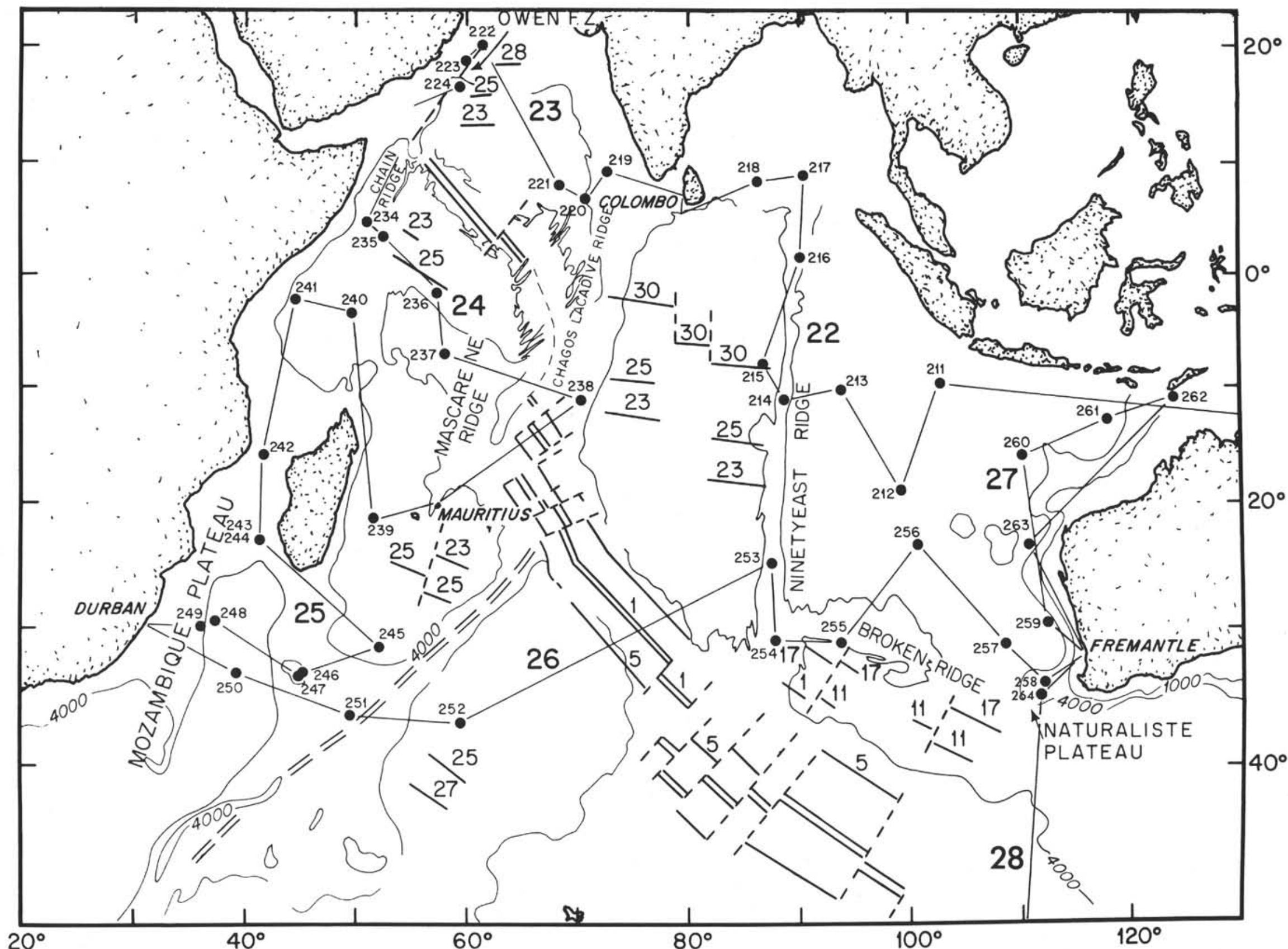

Figure 1. Base chart of the Indian Ocean Basin showing magnetic anomalies, fracture zones, and sea-floor features, all from McKenzie and Sclater (1971). Tracks and sites of the DSDP, Legs 22 through 28, are also shown. 


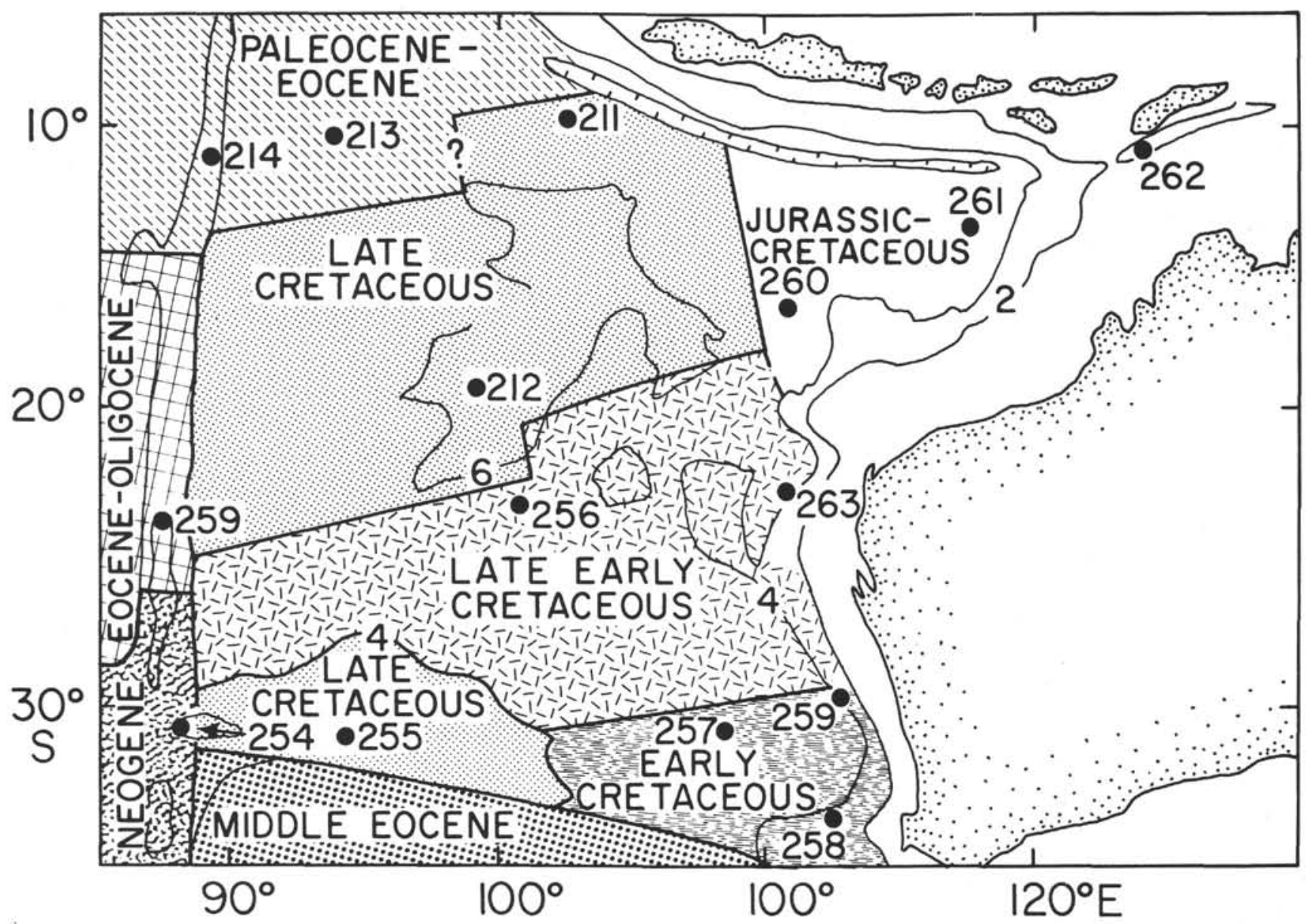

Figure 2. Proposed age provinces in the eastern Indian Ocean based on marine magnetic anomaly data and DSDP sites from Legs 22, 26, 27.

connected east through to ancient Pacific ridge systems (Ben-Avraham and Uyeda, 1973). A Neocomian transgression off northwest Australia suggest that a land mass existed here prior to the Late-Jurassic/EarlyCretaceous spreading (Falvey, 1972a, b). Various authors have suggested that parts of southeast Asia belonged to Gondwanaland and have since rifted away (Ridd, 1971; Audley-Charles et al., 1972). These arguments are beyond the scope of this paper and are definitely data-limited, but paleomagnetic data (Haile and McElhinney, 1972) and the geologic ages in Indonesia (Katili, 1971) suggest that the only likely candidates are Borneo and Celebes. In the earliest Cretaceous this Jurassic ridge became connected to a nascent spreading center to the south between India and Antarctica (Figure 3 b) by a ridge-ridge transform fault - the Darling Fault Zone of west Australia (Geological Society of Australia's Tectonic map of Australia, 1971). This reconstruction predicts continental conditions and sedimentation in extreme western Australia until the Early Cretaceous, a condition which is required by geologic data from this region (Veevers, 1971). A larger than usual India is shown in this reconstruction, the northeastern boundary being defined by north-trending structures (Falvey, 1972b; Dickinson, 1971) and seismicity (Barazangi and Dorman, 1969) in western Burma.

The configuration of the Gondwana continents shown in Figure $4 \mathrm{a}$ is not greatly different from that suggested by DuToit (1937), and McElhinney (1970), among others, and seems to satisfy much equivocal geologic data and more stringent paleomagnetic results. Three megaplates are shown in the figure; an Australia/Antarctic/South America plate, an Africa/Madagascar/Indian plate, and an oceanic plate north of India and Australia (Tethys or Kula plate?; Grow and Atwater, 1970). A spreading ridge between India and Antarctica is connected to a ridge between Africa and South America by a right lateral, ridge-ridge transform fault. This fault is the ancient trace, or the precursor to, the present Southwest Branch (SWB) of the Indian Ocean Ridge. The age of DSDP Sites 257 and 259 in the southeast Wharton Basin and extrapolation of South Atlantic Ocean spreading rates to the Atlantic margins (Le Pichon, 1968; Dietz and Holden, 1970; Le Pichon and Hayes, 1971; Mascle and Phillips, 1972), 


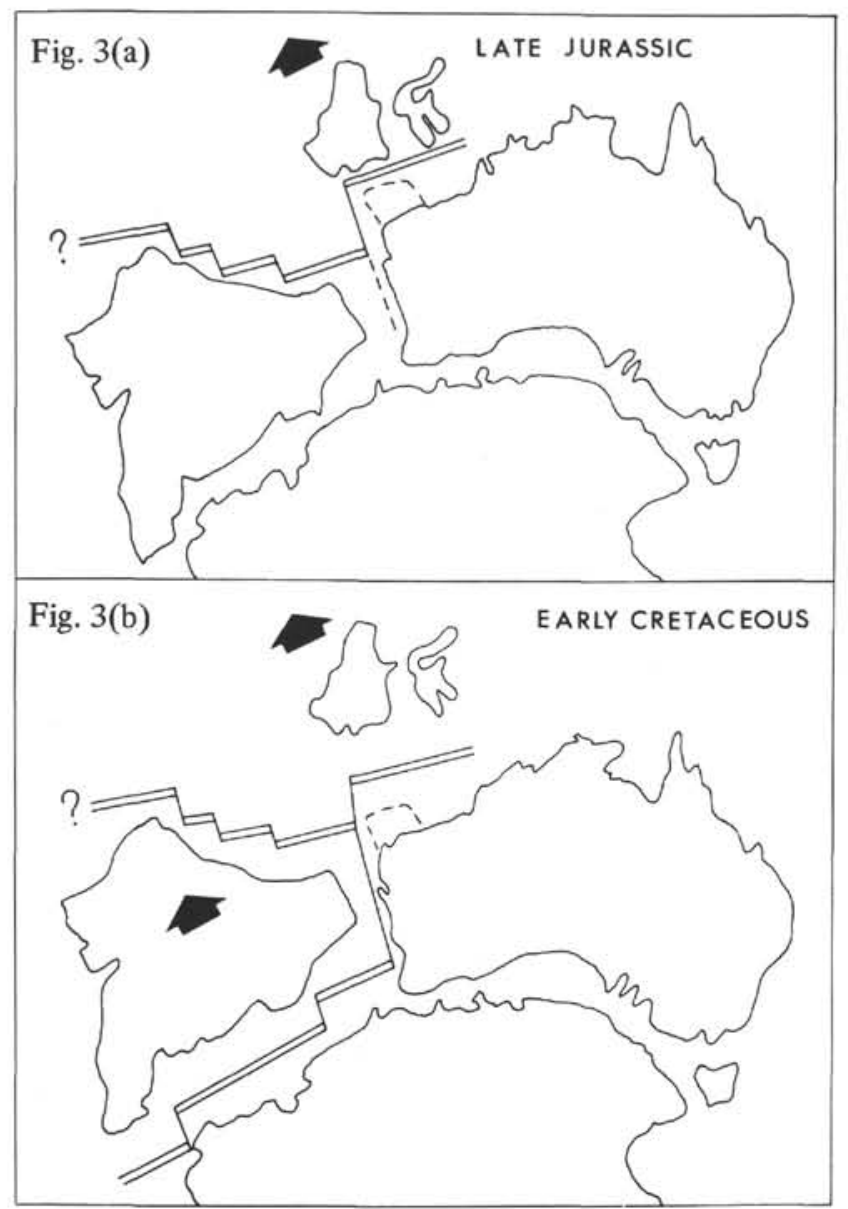

Figure 3. (a) Late Jurassic plate boundaries in the eastern Indian Ocean showing an east-west ridge system separating an ancient landmass from northern Gondwanaland. Mercator projection. (b) The plate system in the Early Cretaceous showing the separation of Indian from Antarctica and Australia. Arrows indicate plate motions relative to Antarctica.

indicate that this phase of spreading (Figure $4 a$ ) or Gondwanaland dispersal, began in the Early Cretaceous (Valanginian according to Larson and Ladd, in press). Africa/Madagascar/India moved away from the rest of Gondwanaland in concert and simultaneously open the extreme South Atlantic and southeastern Indian Ocean. No significant amount of sea floor was created off southeast Africa at this time. The relative motion pole between the Africa et al. and South America et al. plates could have been in the equatorial Atlantic regions. This would restrict and limit marine opening to the southernmost South Atlantic allowing land connections to persist in the northern regions of the South Atlantic. This idea will satisfy many paleontologists who would like Africa and South America to remain in contact until about 90 m.y. B.P. (Reyment and Tait, 1972). These plates and plate motions may have persisted for 20 to 30 m.y. until the Early to mid-Cretaceous when Africa rifted from Antarctica and Madagascar\&India (Figure 4b).
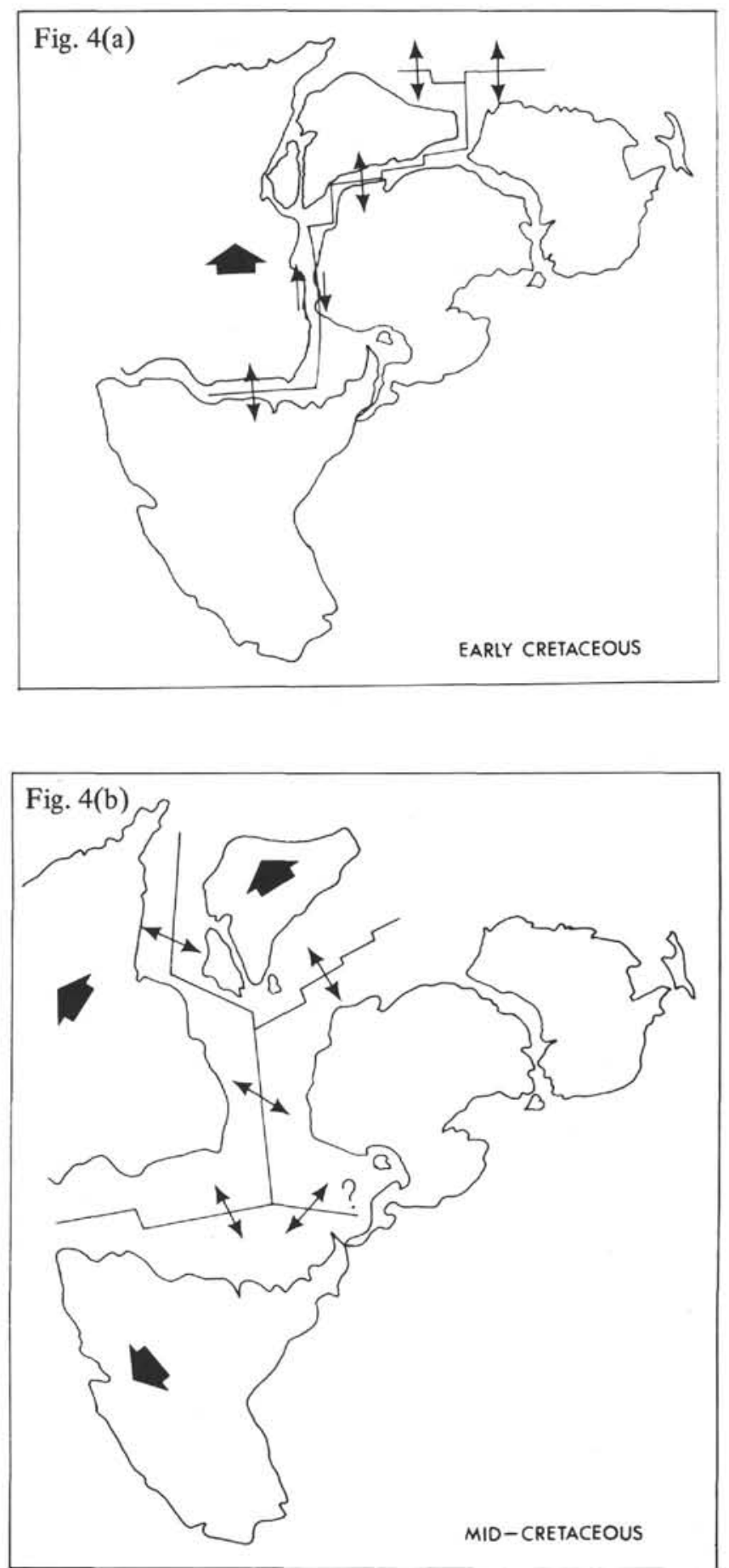

Figure 4. (a) Initial dispersal phase of Gondwanaland in the Early Cretaceous showing a three-plate system and simultaneous opening of the eastern Indian Ocean and southernmost South Atlantic. Arrows show relative motion across plate boundaries; large arrows indicate motion relative to Antarctica. Lambert equal-area projection. Outlines of continents are coastlines. (b) Plate system and Gondwana dispersal in the mid-Cretaceous. (c) Plate system and Gondwana dispersal in the Late Cretaceous and Paleocene. 


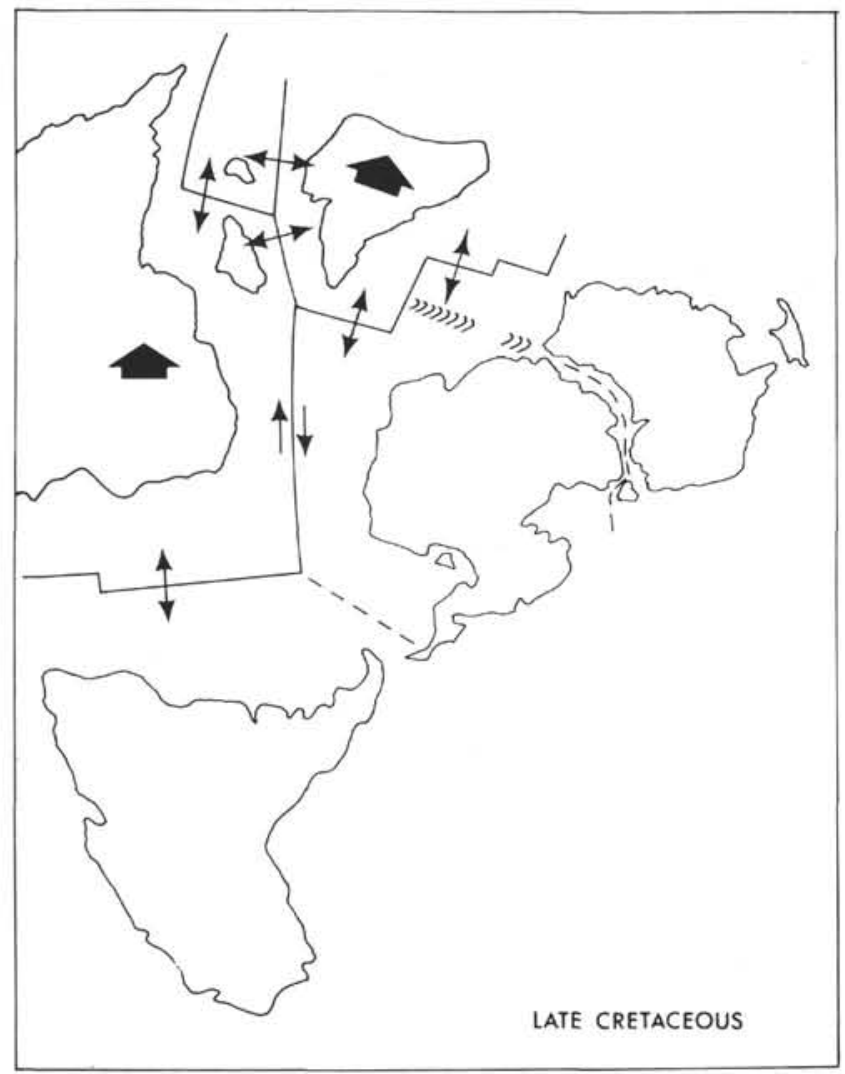

Figure 4c. (Continued).

In Figure 4b Africa is separating from Antarctica by spreading on a Cretaceous analog of the SWB. The transform fault in Figure $4 \mathrm{a}$ has been uplifted and changed to a spreading mode. This ridge is connected via the Davie Ridge (right-lateral transform) in the Mozambique Channel to a spreading center in the Somali Basin. Madagascar is shown separating from Somali, Kenya, and Tanzania as has been indicated by Heirtzler and Burroughs (1971), among others. South America also may have begun moving north at this time (all motions are relative to a fixed Antarctica). Four plates are now shown in Figure 4b: South America, Africa, Madagascar/India, and Australia/Antarctica. The separation of Africa from Madagascar/India has defined a new relative rotation pole between Africa and South America, located further to the north than the previous phase of spreading. This shift in pole location causes the northern portions of the South Atlantic to open later, which is required by biostratigraphic data (Reyment and Tait, 1972). The age of this phase (Figure 4b) of Gondwana dispersal is believed to be midCretaceous. Deep Sea Drilling Project Sites 250 and 249 (Simpson, Schlich, et al., 1972) indicate a midCretaceous or older age for the sea floor immediately off southeast Africa. Cores from the Agulhas Plateau off South Africa also indicate at least a mid-Cretaceous (Cenomanian) age (Saito in Ewing et al., 1969 p. 239). Site 249 dates the Mozambique ridge (Heezen and Tharp, 1965) which evidently is an Aptian or older fracture zone indicating the past relative motion between Africa and Antarctica. The trend of this feature would be essentially parallel to the spreading direction indicated in Figure 4b. Unfortunately, Site 248 (Figure 1) is only $72 \pm 7 \mathrm{~m}$.y. old, based on K-Ar dating of the basalt recovered here (Simpson, Schlich, et al., in press). For this reconstruction, this site would be expected to be mid-Cretaceous or older.

The separation of Africa from Madagascar/India is indicated as mid-Cretaceous or older by Site 241 (Fisher, Bunce, et al. 1972) off Somali. Marine Jurassic sediments are found on the Somali coast (Furon, 1963), but dating this transgression does not necessarily indicate continent dispersal, or creation of oceanic crust. A magnetic smooth zone is strikingly developed over the Somali Basin and parts of southeast Africa (Poehls et al., 1973; Burroughs and Bunce, 1973). If this smooth zone is due to the Cretaceous period of nonreversal, then this evidence supports the idea of rifting of Africa from Madagascar/India and from Antarctica in a time span including 111-85 m.y. B.P. The ancient spreading ridge proposed for the Somali Basin may be buried beneath the thick sediment pile here. No evidence of its existence or absence is currently known. Finally, the northward and slightly westward movement of South America relative to Antarctica may have served to open the Weddell and Scotia seas and to initiate subduction along the northwest front of the Antarctic Peninsula. Based on the proposed upper limit of the Cretaceous uniform polarity interval (Larson and Pitman, 1972), the plate system in Figure $4 \mathrm{~b}$ (or an approximation thereof) persisted until the Late Cretaceous (ca. 85 m.y. B.P.). In the north, off Somali, the Chain Ridge and possibly Owen Fracture Zone mark the east boundary of this spreading phase (Figure $4 \mathrm{~b}$ ) because Chain Ridge bounds the magnetic smooth zone (Burroughs and Bunce, 1973) and Turonian or older (89.6 m.y. B.P.) gabbros were dredged from its flanks (Bunce et al., 1967).

A major reorganization of plates within the Indian Ocean basin in the Late Cretaceous and Paleocene changed the relative motion directions of the Gondwana continents (Figure 4c). Falvey (1972a, b) originally suggested part of this reorganization scheme for the eastern ocean basin. In the western basin a reorganization resulted in the rifting of India from Madagascar in the Paleocene. The age of this rifting is indicated by DSDP Site 239 in the Madagascar Basin (Figure 1) (Simpson, Schlich, et al., 1972), Site 237 on the Seychelles-Saya de Malha ridge (Fisher et al., 1972), and Sites 219 and 220 off the west coast of India (Whitmarsh et al., 1972). The Deccan traps of Paleocene age (Wellman and McElhinney, 1970), in northwest India, also were produced with this rifting. Comparison of Figures $4 \mathrm{~b}$ and $4 \mathrm{c}$ shows that by the Late Cretaceous/Paleocene rifting between Africa and Madagascar and Africa and Antarctica had stopped. The Cretaceous analog of the SWB had reverted to a right-lateral transform fault. McKenzie and Sclater (1971) show the ancient SWB as a right-lateral transform from the Paleocene to the Oligocene. If this is so, then mid-Cretaceous fracture zones on opposite sides of the SWB should show rightlateral offset. Sufficient data are not available to test this 
requirement. Also, the north-south offset of the SWB, south of the Mozambique Ridge or Fracture Zone (see Heezen and Tharp, 1965), argues against significant right-lateral movement unless this offset is Oligocene or younger. The resolution of this question is presently ambiguous.

In the northern Indian Ocean two spreading ridges separate the Seychelles Bank from India and from Madagascar. These ridges may or may not have existed contemporaneously. The shape of the western limbs of this triple junction shown in Figure $4 \mathrm{c}$ matches the trends of the Seychelles-Saya de Malha and Mascarene ridge. The trends join at an oblique angle of about $110^{\circ}$ to form a topographic bight, concave to the southwest (Figure 1). The first rifting may have been between Madagascar and Seychelles/India and the early "leaky" phases of the rifting may have created the SeychellesSaya de Malha and Mascarene ridges. The trend of the proposed ridge between the Seychelles and India is unknown as it has been buried beneath continental margin and Indus Cone sediments and/or subducted (?) beneath Iran-Pakistan. If its trend was more northeasterly than shown in Figure 4c, it could have formed an angle of about $120^{\circ}$ to the other spreading branches at the triple junction. Based on some current hypotheses (Dewey and Burke, 1973), this triple junction may have resulted from crustal upwarping caused by a mantle plume or hot spot. In this case the Deccan traps would be expected to show theoretical "hot spot" petrochemical affinities. Davies (1968) has also suggested that Seychelles rifted from India in the Paleocene. As the India-Madagascar ridge migrated easterly relative to Africa, it may have lined up to be more parallel to the SWB transform and have reverted to the left-lateral transform fault indicated by McKenzie and Sclater (1971) for this region in the Paleocene. Possibly simultaneously, the Seychelles-Madagascar ridge jumped north of the Seychelles to connect the India-Madagascar transform with the Owen Fracture Zone (shown as the transform off Somali in Figure 4c; see McKenzie and Sclater, 1971). Other plate reorganizations in the Paleocene include overprint of the previous IndiaAntarctica ridge (Figure 4b) by an ancient analog of the Southeast Branch (SEB) of the Indian Ocean Ridge.

Another tectonic event during this time period, or possibly shortly before, was incipient rifting of Australia from Antarctica. In Figure 4c this rifting is shown to occur simultaneously with the formation of Broken Ridge and Kerguelen Plateau. Results from Site 255 (Leg 26) indicate that Broken Ridge has existed since at least the Santonian and is possibly older. Kaharoeddin et al., (in press) also report recovery of Cenomanian chalk ooze from the Kerguelen Plateau. Naturaliste Plateau (Site 258) is at least Middle Albian in age, so that if the Broken Ridge/ Kerguelen Plateau and the Naturaliste Plateau are contemporary volcanic features, then the incipient rift between Australia and Antarctica may be more properly proposed for the mid-Cretaceous (Figure 4b). Cretaceous rifting would be in agreement with the observation of a magnetic smooth zone (Cretaceous?) over the Australian and Antarctic continental margins (Poehls et al., 1973; Weissel and Hayes, 1971) and a marine transgression in southern Australia (Brown et al., 1968) during this time period.
The reconstruction in Figure $4 \mathrm{c}$ also indicates that the northward motion of South America has slowed but evidently the Davis Strait has opened. Therefore, the first analog of the circumpolar current may not have existed until the Late Cretaceous and Paleocene. As indicated above, the SWB changed from a spreading ridge in the mid to Late Cretaceous to a transform fault in the Late Cretaceous and Paleocene. Concomitant with this change was a subsidence of the sea floor below the carbonate compensation depth in the Late Cretaceous as the dying SWB ridge thermally contracted. This subsidence may explain the dissolution facies, older than Coniacian age, which is found at the base of Site 250 .

To summarize then, the basic framework of the Gondwanaland dispersal proposed here is:

1) Opening of the eastern Indian Ocean and southerly portions of the South Atlantic simultaneously in the Early Cretaceous.

2) Opening of the northwestern and southwestern Indian Ocean and equatorial South Atlantic in the midCretaceous (Aptian?) to Late Cretaceous (Coniacian) with the rifting of Africa from Antarctica and from Madagascar/India.

3) Opening of the Central Indian Ocean with the rifting of Madagascar from India in the Late Cretaceous and Paleocene. McElhinney (1970) and Smith and Hallam (1970) have also considered both the fit and dispersal of Gondwana continents. Both show a reconstruction as in Figure 4a, based on paleomagnetic data and computerized matching of continental edges, respectively. The sea-floor data discussed above mainly lend support to the India-Antarctica fit proposed by these authors. Other Gondwana fits have been assumed a priori in the present discussion. It is the dispersal scheme which is constrained to a finer degree by the seafloor data than the continental data used by McElhinney (1970), and Smith and Hallam (1970). Because the dispersal phase is related to the creation of sea floor in the intercratonic rifts (DuToit, 1937; Smith and Hallam, 1970) dating dispersal from continent geology is uncertain. Volcanism, marine sedimentation, and faunal similarities or differences can indicate continent break-up and rifting but not necessarily dispersal (see discussion in Smith and Hallam, 1970). Accordingly, Smith and Hallam (1970) noted that the date of the dispersal of Africa from Antarctica and from Madagascar is unknown. Using sea-floor spreading and paleomagnetic data, they concluded that the separation of Africa from India, Madagascar from India, and Antarctica from India was in the Tertiary and that South America separated from Africa in the Cretaceous.

McElhinney's scheme of dispersal, based on paleomagnetic data, has some important differences from the one proposed here. The first dispersal scheme is between South America and Africa sometime between the Late Triassic and Early Cretaceous. However, the first opening of the Indian Ocean is in the west before the mid-Cretaceous and after the mid-Jurassic with the separation of Africa from the rest of the Gondwana continents. Although the paleomagnetic data permit various interpretations, McElhinney favors the rifting of India form Antarctica. The reason for this discrepancy is not immediately apparent. Paleomagnetic data, 
however, do support the dispersal of Madagascar from India in the Paleocene (McElhinney, 1970). An interesting fact brought out by McElhinney's paleomagnetic data is that the early opening of the Indian Ocean is mainly accomplished by southward movement of Gondwana continents away from Africa (I would suggest southward from India also). Reconstructions of postulated relative motions in Figure 4 are relative to a fixed Antarctica with paleomagnetic latitudes being neglected in this analysis.

Future work should include resolution of this dispersal scheme with paleomagnetic data, hopefully preceded by additional sea-floor observations. Such observations might include charting and study of Early Cretaceous magnetic lineations which are predicted to occur off East Antarctica, southwest Australia, eastern India, and Ceylon, and the continental margins of South Africa and Argentina. Cenozoic lineations should be searched for over the Mascarene Basin between the Seychelles, the Mascarene Ridge, Madagascar, and off western India. Charting of old fracture zone trends in portions of the sea floor shown in Figure 4b would aid in determining relative motion directions during a geologic period which was essentially free of magnetic field reversals. Finally, any additional DSDP holes in the sea floor of Figures $4 \mathrm{~b}$ and $4 \mathrm{c}$ would aid the problem in an obvious manner. Sites located as close as possible to the continental edges would be specially worthwhile.

\section{ACKNOWLEDGMENTS}

This work was supported by the Office of Naval Research Contract N00014-66-CO-241 to the Woods Hole Oceanographic Institution. This manuscript was reviewed by John Sclater, J. R. Heirtzler, and Zvi Ben-Avraham, who do not necessarily support its conclusions.

\section{REFERENCES}

Audley-Charles, M. G., Carter, D. J., and Milsom, J. S., 1972. Tectonic development of eastern Indonesia in relation to Gondwanaland dispersal: Nature, v. 239, p. 35-39.

Barazangi, M. and Dorman, J., 1969. World seismicity maps compiled from ESSA Coast and Geodetic Survey, epicenter data, 1961-1967: Seism. Soc. Am. Bull., v. 59, p. 369-380.

Ben-Avraham, Z. and Uyeda, S., 1973. The evolution of the China Basin and the Mesozoic paleogeography of Borneo: Earth Planet. Sci. Lett., v. 18, p. 365-376.

Brown, D. A., Cambell, K., and Crook, K., 1968. The geological evolution of Australia and New Zealand: Oxford (Pergamon Press).

Bunce, E. T., Langseth, M. G., Chase, R. L., and Ewing, M., 1967. Structure of the western Somali Basin: J. Geophys. Res., v. 72 , p. $2547-2555$.

Burroughs, R. and Bunce, E. T., 1973. Chain ridge: jmplications for northwestern Indian Ocean evolution (abstract), Am. Geophys. Un. Trans., v. 54, p. 330.

Crawford, A. R., 1969. India, Ceylon and Pakistan: new age data and comparisons with Australia: Nature, v. 223, p. 380-383.

Davies, D., 1968. When did the Seychelles separate from India?: Nature, v. 220, p. 1225-1226.

Dewey, J. and Burke, K., 1973. Plume generated triple junctions (abstract): Am. Geophys. Un. Trans., v. 54, p. 239.
Dickinson, W. R., 1971. Plate tectonic models for orogeny at continental margins: Nature, v. 232, p. 41-42.

Dietz, R. S. and Holden, J. C., 1970. Reconstruction of Pangea: breakup and dispersion of continents, Permian to Present: J. Geophys. Res., v. 75, p. 4939-4956.

DuToit, A. L., 1937. Our wandering continents: Edinburgh and London (Oliver and Boyd).

Ewing, M., Eittreim, S., Truchan, M., and Ewing, J., 1969. Sediment distribution in the Indian Ocean: Deep-Sea Res., v. 16 , p. $231-248$.

Falvey, D. A., 1972a. The nature and origin of marginal plateaux and adjacent ocean basins off northern Australia: Ph.D. thesis, Univ. New South Wales, Sydney.

1972 b. Sea-floor spreading in the Wahrton Basin (northeast Indian Ocean) and the breakup of eastern Gondwanaland: Aust. Petrol. Expl. Assoc. J., v. 12, p. 8688.

Fisher, R. L., Bunce, E. T., Cernock, P. J., Clegg, D. C., Cronan, D. S., Damiani, V. V., Dmitriev, L., Kinsman, D. J. J., Roth, P. H., Thiede, J., and Vincent, E. S., 1972. Deep Sea Drilling Project in dodo land, Leg 24: Geotimes, v. 17, p. 17-21.

Furon, R., 1963. Geology of Africa: Edinburgh and London, (Oliver and Boyd).

Geological. Society of Australia, 1971. Tectonic map of Australia and New Guinea, 1:5,000,000.

Grow, J. and Atwater, T., 1970. Mid-Tertiary tectonic transition in the Aleution Arc: Geol. Soc. Am. Bull., v. 81, p. 3715-3721.

Haile, N. S. and McElhinney, M., 1972. The potential value of paleomagnetic studies in restraining romantic speculation about the geological history of southeast Asia (abstract): Regional Conf. Geol. Southeast Asia, Kuala Lumpur, Malaysia, Abstracts of papers, p. 20-25.

Heezen, B. C. and Tharp, M., 1965. Tectonic fabric of the Atlantic and Indian Oceans and continental drift: Phil. Trans. Roy. Soc. London, Series A, v. 258, p. 90-106.

Heirtzler, J. R. and Burroughs, R., 1971. Madagascar's paleoposition: new data from the Mozambique Channel: Science, v. 174, p. 488-490.

Heirtzler, J. R., Dickson, G. O., Herron, E. M., Pitman, W. C., III, and Le Pichon, X., 1968. Marine magnetic anomalies, geomagnetic field reversals, and motions of the ocean floor and continents: J. Geophys. Res., v. 73, p. 2119-2136.

Heirtzler, J. R., Veevers, J. J., Bolli, H. M., Carter, A. N., Cook, P. J., Krasheninnikov, V. A., McKnight, B. K., Proto-Decima, F., Renz, G. W., Robinson, P. T., Rocker, K., and Thayer, P. A., 1973a. Age of the floor of the eastern Indian Ocean: Science, v. 180, p. 952-954.

1973b. Deep Sea Drilling Project, Leg 27, in the eastern Indian Ocean, Geotimes, v. 18, p. 16-17.

Kaharoeddin, A., Weaver, F. M., and Wise, S. W., in press. Cretaceous and Paleogene cores from the Kerguelen Plateau, southern ocean: Antarc. J. U.S.

Katili, J. A., 1971. A review of the geotectonic theories and tectonic maps of Indonesia: Earth Sci. Rev., v. 7, p. 143163.

Larson, R. L. and Ladd, J., 1973. Evidence for the opening of the South Atlantic in the Early Cretaceous: Nature, v. 246, p. 209-212.

Larson, R. L. and Pitman, W. C., III, 1972. World-wide correlation of Mesozoic magnetic anomalies: and its implications: Geol. Soc. Am. Bull., v. 83, p. 3645-3662.

Le Pichon, X., 1968. Sea-floor spreading and continental drift: J. Geophys. Res., v. 73, p. 3661-3705.

Le Pichon, X. and Hayes, D., 1971. Marginal offsets, fracture zones and the early opening of the South Atlantic: J. Geophys. Res., v. 76, p. 6283-6293. 
Lowrie, A., Bracey, D. R., and Vogt, P., 1972. Geophysical surveys in the eastern Indian Ocean and Caroline Basin; preliminary results (abstract): Am. Geophys. Un. Trans., v. 53, p. 413.

Luyendyk, B. P., Davies, T. A., Rodolfo, K. S., Kempe, D. R. C., McKelvey, B. C., Leidy, R. D., Horvath, G. J., Hyndman, R. D., Theirstien, H. R., Boltovskoy, E., and Doyle, P., 1973. Across the southern Indian Ocean aboard Glomar Challenger: Geotimes, v. 18, p. 16-19.

Mascle, J. and Phillips, J. D., 1972. Magnetic smooth zones in the South Atlantic: Nature, v. 240 , p. $80-84$.

McElhinney, M., 1970. Formation of the Indian Ocean: Nature, v. 228, p. 977-979.

McKenzie, D. and Sclater, J. G., 1971. The evolution of the Indian Ocean since the Late Cretaceous: Geophys. J. Roy. Astron. Soc., v. 25, p. 437-528.

Poehls, K., Luyendyk, B. P., and Heirtzler, J. R., 1973. Magnetic smooth zones in the world's ocean: J. Geophys. Res., v. 78, p. 6985-6997.

Reyment, R. A. and Tait, E. A., 1972. Biostratigraphical dating of the early history of the south Atlantic Ocean: Phil. Trans. Roy. Soc. London, v. 264, p. 55-95.

Ridd, M. F., 1971. Southeast Asia as part of Gondwanaland: Nature, v. 234, p. 531-533.

Schouten, J. and McCamy, K., 1972. Filtering marine magnetic anomalies: J. Geophys. Res., v. 77, p. 7089-7099.

Sclater, J. G. and Fisher, R. L., 1973, in press. The evolution of the east central Indian Ocean, with emphasis on the tectonic setting of the Ninetyeast Ridge: Geol. Soc. Am.

- Bull.
Simpson, E., Schlich, R., Leclaire, L., Moore, C., Girdley, W. A., White, S. M., Vallier, T., Muller, C., Zobel, B., Sigal, J., Gieskes, J. and Marshall, B. V., 1972. Leg 25, Deep Sea Drilling Project, Western Indian Ocean: Geotimes, v. 17, p. 21-24.

in press. Initial Reports of the Deep Sea Drilling Project, Volume 25. Washington (U.S. Government Printing Office).

Smith, A. and Hallam, A., 1970. The fit of the southern continents: Nature, v. 225, p. 139-144.

Veevers, J. J., Jones, J. G., and Talent, J. A., 1971. IndoAustralian stratigraphy and the configuration and dispersal of Gondwanaland: Nature, v. 229, p. 383-388.

Veevers, J. J., 1971. Phanerozoic history of western Australia related to continental drift: J. Geol. Soc. Aust., v. 18, p. 8796.

von der Borch, C., Sclater, J. G., Gartner, S., Jr., Hekinian, R., Johnson, D. A., McGowran, B., Pimm, A. C., Thompson, R. W., and Veevers, J. J., 1972. Deep Sea Drilling Project, Leg 22: Geotimes, v. 17, p. 15-17.

Wegener, A., 1929. The origin of the continents and oceans: New York (Dover) (trans. by J. Biram from German ed. 4.)

Weissel, J. and Hayes, D., 1971. Asymmetric sea-floor spreading south of Australia: Nature, v. 231, p. 518-522.

Wellman, P. and McElhinney, M., 1970. K-Ar age of the Deccan traps, India: Nature, v. 227, p. 595-596.

Whitmarsh, R. B., Weser, O., Ali, S., Boudreaux, J. E., Matter, A., Nigrini, C., Siddiquie, H. N., and Stoffers, P., 1972. Deep Sea Drilling Project in the Arabian Sea: Geotimes, v. 17 , p. 22-24. 